\title{
PENGEMBANGAN MEDIA PEMBELAJARAN MEMBACA AWAL DENGAN MENGGUNAKAN KARTU SUKU KATA KELAS I SEKOLAH DASAR
}

\author{
Masitah Bahrun \\ Universitas Mulawarman \\ masitahbahrun@gmail.com
}

Tujuan penelitian ini adalah (1) untuk mengembangkan media pembelajaran membaca awal dengan menggunakan kartu suku kata di Kelas 1 Sekolah Dasar, (2) untuk mengetahui kelayakan pengembangan media pembelajaran membaca awal dengan menggunakan kartu suku kata di Kelas 1 Sekolah Dasar, dan (3) untuk mengetahui efektifitas pengembangan media pembelajaran membaca awal dengan menggunakan kartu suku kata di Kelas 1 Sekolah Dasar. Data dikumpulkan melalui observasi, angket validasi, tes kelas dan dokumentasi. Teknik Analisa data yang digunakan adalah analisis data kualitatif dan data kuantitatif. Analisa data kualitatif untuk mendeskripsikan pendapat, saran, dan tanggapan validator, sedangkan data kuantitatif digunakan untuk mengolah data hasil observasi penilaian produk dan tes kelas. Hasil pengembangan produk menunjukkan (1) pengembangan media pembelajaran kartu suku kata dilakukan melalui 3 tahap, sehingga hasil pengembangannya terlihat pada penggabungan huruf menjadi suku kata, mengeja suku kata menjadi kata, menggabungkan kata menjadi kalimat, membaca suku kata pada kartu suku kata, memasang kata dengan gambar, da melengkapi kata dalam kalimat; (2) hasil pengembangan media pembelajaran kartu suku kata dikategorikan sangat layak dengan skor rata rata yang diberikan oleh ahli materi yaitu 91\% kategori sangat layak, ahli media \& desain yaitu 76,11 kategori layak; dan (3) efektivitas pengembangan media pembelajaran ditandai oleh hasil belajar ketika belajar uji coba media terhadap siswa dan keberhasilan pelaksanaan pembelajaran berdasarkan perencanaan pembelajaran yang telah dilakukan berdasarkan data yg diperoleh dari uji coba awal kelompok kecil dengan nilai rata rata $73,37 \%$ dan nilai akhir uji kelompok kecil meningkat menjadi $87,14 \%$, sedangkan hasil yg dicapai pada uji awal kelompok besar atau uji lapangan nilai rata rata $88,54 \%$ sedangkan uji akhir kelompok besar atau uji lapangan terdapat peningkatan dengan nilai rata rata 89,69 \%. Secara umum dapat disimpulkan bahwa pengembangan media pembelajaran kartu suku kata dapat meningkatkan siswa dalam membaca awal.

\section{Kata Kunci: media pembelajaran, membaca awal, kartu suku kata}

\section{ABSTRACT}

The objectives of this study: (1) to develop early reading learning media using syllable cards in Grade 1 Elementary Schools, (2) to determine the feasibility of developing early reading learning media using syllable cards in Grade 1 Elementary Schools, and (3) to determine the effectiveness of the development of early reading learning media using syllable cards in Grade 1 Elementary School. Data were collected through observation, validation questionnaires, class tests and documentation. The data analysis technique used is qualitative data analysis and quantitative data. Qualitative data analysis is used to describe the validator's opinions, suggestions, and responses, while quantitative data is used to process data from observations of product assessments and class tests. The results of the product development show (1) the development of learning media for syllable cards is carried out in 3 stages, so that the results of the development can be seen in combining letters into syllables, spelling syllables into words, combining words into sentences, reading syllables on syllable cards, installing words with pictures, da completes the words in the sentence; (2) the results of the development of the syllable card learning media were categorized as very feasible with the average score given by the material expert, namely 91\%, very feasible category, media \& design expert, namely 76.11 feasible category; and (3) the effectiveness of the development of learning media is characterized by learning outcomes when learning media trials against students and the success of learning implementation based on learning planning that has been carried out based on data obtained from small group initial trials with an average value of $73.37 \%$ and the final score. The small group test increased to $87.14 \%$, while the results achieved in the initial large group test or field test had an average value of $88.54 \%$ while the large group final test or field test had an increase with an average value of $89.69 \%$. In general, it can be concluded that the development of syllable card learning media can improve students' pre-reading reading.

Keywords: learning media, pre-reading, syllable cards

\section{PENDAHULUAN}

Pembelajaran Bahasa Indonsia terdiri dari keterampilan menyimak keterampilan berbicara, keterampilan membaca dan keterampilan menulis. Keempat keterampilan tersebut saling bertalian satu dengan yang lain. Membaca awal diberikan pada siswa Kelas 1 dan 2. Tujuannya adalah agar siswa memiliki kemampuan memahami dan menyuarakan tulisan dengan intonasi yang wajar.

Standar Kompetensi Lulusan (SKL) (Peraturan Menteri Pendidikan Nasional Republik Indonesia Nomor 20 Tahun 2016) "Sekolah Dasar (SD) Kurikulum 2013 domain pengetahuan: mengamati, menanya, mencoba, mengolah, menyajikan, menalar, mencipta".

Selanjutnya dalam Kompetensi Inti Kelas 1 domain Pengetahuan : Memahami pengetahuan faktual dengan cara mengamati (mendengar, melihat dan membaca) dan menanya berdasarkan rasa ingin tahu tentang dirinya, makhluk ciptaan Tuhan dan kegiatannya, dan benda-benda yang dijumpainya di rumah dan di sekolah.

Sesuai dengan Pasal 2 (Undang-Undang Republik Indonesia No.20, 2003) tentang Sistem Pendidikan Nasional, bahwa "pendidikan nasional berdasarkan Pancasila dan Undang-Undang Dasar Negara Republik Indonesia Tahun 1945". Sedangkan Pasal 3 menegaskan bahwa "pendidikan nasional berfungsi mengembangkan kemampuan dan membentuk watak serta peradaban bangsa yang bermartabat dalam rangka mencerdaskan kehidupan bangsa, bertujuan untuk mengembangkan potensi peserta didik agar menjadi manusia yang beriman dan bertakwa kepada Tuhan Yang Maha Esa, 
berakhlak mulia, sehat, berilmu, cakap, kreatif, mandiri, dan menjadi warga negara yang demokratis serta bertanggung jawab".

Untuk mewujudkan tujuan pendidikan nasional tersebut diperlukan profil kualifikasi kemampuan lulusan yang dituangkan dalam standar kompetensi lulusan. Dalam penjelasan Pasal 35 Undang-Undang Nomor 20 Tahun 2003 disebutkan bahwa "standar kompetensi lulusan merupakan kualifikasi kemampuan lulusan yang mencakup sikap, pengetahuan, dan keterampilan peserta didik yang harus dipenuhinya atau dicapainya dari suatu satuan pendidikan pada jenjang pendidikan dasar dan menengah".

Dalam lampiran (Peraturan Menteri Pendidikan Nasional Republik Indonesia Nomor 22, 2016) tentang Standar Proses Pendidikan Dasar dan Menengah dinyatakan bahwa

"Komponen Rencana Pelaksanaan pembelajaran terdiri dari atas : a) Identitas sekolah; b) Identitas mata pelajaran; c) kelas/semester; d) Materi pokok; e) Alokasi waktu; f) Tujun pembelajaran yang dirumuskan berdasarkan $\mathrm{KD}$ dengan menggunakan kata kerja operasional yang dapat diamati dan diukur yang mencakup sikap,pengetahuan dan keterampilan; g) Kompetensi dasar dan Indikator pencapaian kompetensi; h) Materi pembelajaran; i) Metode pembelajaran; j) Media pembelajaran; k) Sumber belajar; 1) langkah-langkah pembelajaran; m) Penilaian hasil pembelajaran.”

\section{Kompetensi Inti dan Kompetensi Dasar} (Permendikbud No. 24 Tahun 2016) "bahasa Indonesia 3.8; Merinci ungkapan penyampaian terimakasih, permohonan maaf, tolong dan pemberian pujian, ajakan, pemberitahuan, perintah, dan petunjuk kepada orang lain dengan menggunakan bahasa yang santun secara lisan dan tulisan yang dapat dibantu dengan kosakata bahasa daerah. Komunikasi lisan mencakup keterampilan menyimak dan berbicara. Sedangkan komunikasi tertulis mencakup keterampilan membaca dan menulis. Keterampilan membaca awal sebagai salah satu keterampilan berbahasa merupakan suatu keterampilan yang harus dimiliki siswa SD agar mampu berkomunikasi secara lisan".

Menggunakan kurikulum 2013 diharapkan sikap ilmiah yang harus lebih dahulu dilatihkan adalah kemampuan untuk menghargai orang lain dan keberanian siswa untuk menjawab pertanyaan, mengajukan pertanyaan, dan diskusi. Untuk mengembangkan sikap-sikap tersebut diperlukan aturan dan motivasi dari guru di kelas (Samatowa, 2011). Hal tersebut di atas memberikan tuntunan pada pembelajaran Tema peristiwa alam Sub Tema peristiwa siang dan malam agar menerapkan media pembelajaran siswa untuk melakukan proses ilmiah yang sekaligus dapat mengembangkan sikap-sikap ilmiah (saintific attitude).

Pembelajaran membaca awal pada aspek keterampilan berbahasa di SD 024 Samarinda Utara masih rendah. Hal itu terlihat dari hasil observasi ke1 siswa di kelas ID SDN No.024 Samarinda Utara yang berjumlah 28 orang, terdapat 4 orang siswa yang baru mampu mengenal huruf, 10 orang siswa belum lancar membaca dan 14 telah lancar membaca. Berdasarkan hasil observasi ke-2 berdasarkan nilai ulangan harian B.Indonesia di kelas ID memperoleh rata-rata 70 dengan Kreteria Ketuntasan minimum (KKM) 75 sehingga belum maksimal mengerjakan tugas-tugas yang diberikan guru. Beberapa penyebab anak-anak kurang lancar membaca disebabkan komunikasi membaca yang satu arah, media yang digunakan guru hanya huruf tanpa disertai gambar, cara membaca siswa menggunakan kalimat sederhana sementara siswa belum dapat membaca suku katanya. Upaya untuk pembelajaran membaca awal dapat dilakukan dilapangan saat penelitian adalah (1) pengadaan berbagai buku teks pelajaran (2) penerapan berbagai media dalam pembelajaran.

Penggunaan media pembelajaran dalam proses belajar mengajar sangat penting disebabkan dapat menumbuhkan minat belajar siswa, rasa ingin tahu siswa, motivasi dan rangsangan kegiatan belajar siswa. Penggunaan media pada tahap orentasi pengajaran akan sangat membantu keefektifan proses pembelajaran dan pesan dan isi pembelajaran pada waktu itu (Wiratmojo, 2002).

Permasalahan lainnya adalah literasi sains siswa selama ini kurang mendapat perhatian guru dalam melaksanakan pembelajaran. Guru dalam pembelajaran sangat jarang memberikan kesempatan kepada siswanya untuk memahami fenomenafenomena di sekitarnya berdasarkan konsep-konsep yang dipelajarinya. Guru lebih berorientasi pada materi yang tercantum pada kurikulum dan buku teks, sehingga siswa kurang antusias dalam proses pembelajaran. Pembelajaran menjadi kurang bermakna, karena siswa tidak mampu mengaitkan konsep dalam kehidupan sehari-hari). Oleh karena itu media pembelajaran kartu suku kata perlu diuji efektivitasnya dalam meningkatkan sikap ilmiah siswa sekolah dasar.

Adapun penelitian ini yang dilakukan oleh peneliti saat ini adalah pengembangan bahan ajar dengan menggunakan kartu kata dengan gambar yang disesuaikan temanya dengan tematik Kurikulum 2013. Pada penelitian ini pun tidak hanya 
fokus pada 1 aspek kognitif saja, namun media kartu kata ini mencakup pada berbagai aspek, khususnya apsek sosial emosional pada anak. Dengan media ini siswa dapat meningkatkan motivasi, minat serta semangat belajar. Agar lebih mudah lagi mengenal kata maka sebelumnya disusun terlebih dahulu mengenal sukukatanya dan disertai gambar. Siswa akan termotivasi lagi dengan usaha penyusunan suku kata berkelompok sehingga bukan saja penilaian pengetahuan membaca saja tetapi nilai sosial yang terjadi pada siswa akan terlihat seperti kerjasama, tolong menolong, kepeminpinan dan saling menghargai. Materi yang disampaikan dalam penelitian ini adalah pembelajaran pada kurikulum 2013 dengan tema peristiwa alam dengan sub tema siang dan malam..

\section{METODE}

Metodologi pada penelitian ini adalah jenis penelitian dan pengembangan atau Research and Development (R\&D) dengan metode pengembanggan ADDIE. Menurut (Sugiyono, 2015), Research and Development (R\&D) merupakan jenis penelitian yang digunakan untuk menghasilkan suatu produk. Metode yang digunakan pada penelitian ini mengunakan model pengembangan dengan pendekatan ADDIE menurut (Branch, 2009) terdapat 5 tahapan, yaitu (1) analysis, (2) design, (3) development, (4) implementation, dan (5) evalution. Sedangkan menurut Branch (2009: 2), metode penelitian R\&D memiliki 5 langkah, dikenal dengan pendekatan ADDIE yaitu singkatan dari Anaysis, Design, Development, Implementation, dan Evaluation.

\section{Tempat dan Waktu Penelitian}

Tahap analisis dari penelitian dan pengembangan ini dilakukan dengan observasi di kelas ID SDN No.024 Samarinda Utara tahun pembelajaran 2019/2020. Penelitian ini dilaksanakan mulai dari tahap persiapan hingga selesai tahap pelaksanaan, dimulai pada bulan Februari 2020 sampai dengan 30 April 2020.

\section{Tehnik Pengumpulan Data}

Tehnik pengumpulan data yang digunakan dalam penelitian ini terdiri atas teskelas,observasi dan dokumentasi.

\section{Instrumen Penelitian}

Instrumen penelitian yang digunakan yaitu: intrumen tes awal dan akhir, lembar observasi guru dalam pelaksanaan penggunakan kartu suku kata.
Penelitian ini menggunakan angket validasi. Pengujian validasi yang dilakukan oleh ahli materi dan ahli media \&desain yaitu Dr. H. Yusak Hudiyono, M.Pd dan Dr. Sudarman, S.Pd, M.Pd sehingga kelayakan media pembelajaran kartu suku kata dapat digunakan pada membaca awal di kelas I Sekolah Dasar.

\section{Tehnik Analisis Data}

Analisis data dilakukan untuk melihat nilai masing masing aspek. Data diperoleh dari angket yang diberikan kepada ahli materi,ahli media \& desain dan hasil tes kelas peserta didik. Tehnik analisis data menpunyai langkah langkah sebagai berikut:

a. Data kuantitatif digunakan untuk mengolah data berbentuk angka-angka yang diperoleh melalui angket-angket penilaian produk menggunakan skala likert yaitu; sangat baik (SB), baik (B), cukup (C), kurang (K), dan sangat kurang (SK)

Ketentuan Pemberian Skor

\begin{tabular}{|l|c|}
\hline \multicolumn{1}{|c|}{ Kategori } & Skor \\
\hline Sangat baik (SB) & 5 \\
\hline Baik (B) & 4 \\
\hline Cukup (C) & 3 \\
\hline Kurang ( K) & 2 \\
\hline Sangat Kurang (SK) & 1 \\
\hline
\end{tabular}

Sumber: Sugiyono (2017:166)

Menghitung skor rata-rata dengan rumus:

$\bar{x}=\frac{\Sigma \mathrm{X}}{\mathrm{N}}$

Keterangan :

$\bar{x}=$ rerata skor tiap komponen

$\sum \mathrm{X}=$ jumlah skor

$N=$ jumlah indikator yang dinilai

b. Angka-angka yang diperoleh melalui angketangket menggunakan skala likert kemudian dianalisis melalui perhitungan persentase skor item pada setiap pertanyaan dalam angket. Adapun rumus persentase yang peneliti gunakan adalah sebagai berikut:

$\mathrm{P}=\frac{\sum x}{\sum x i} \times 100 \%$

Keterangan:

P : Persentase kelayakan / kevalidan

$\sum \mathrm{x}$ : Jumlah skor yang diperoleh dari validator

$\sum x i$ : Jumlah skor maksimal

Hasil yang diperoleh dari perhitungan persentase kemudian ditentukan tingkat kelayakan dan kevalidannya menggunakan konversi skala tingkat pencapaian sebagai berikut:

Konversi Tingkat Pencapaian dengan Skala Lima 


\begin{tabular}{|c|c|c|c|}
\hline $\begin{array}{l}\text { Skala } \\
\text { Likert }\end{array}$ & Skor & Kategori & Kreteria \\
\hline 1 & $\begin{array}{l}0 \%- \\
54 \%\end{array}$ & $\begin{array}{c}\text { Sangat } \\
\text { Kurang } \\
\text { Layak }\end{array}$ & $\begin{array}{l}\text { Produk } \\
\text { gagal, } \\
\text { revisi } \\
\text { totalisi } \\
\text { produk }\end{array}$ \\
\hline 2 & $\begin{array}{l}55 \%- \\
59 \%\end{array}$ & $\begin{array}{c}\text { Kurang } \\
\text { Layak }\end{array}$ & $\begin{array}{l}\text { Revisi } \\
\text { dengan } \\
\text { meneliti } \\
\text { kembali } \\
\text { bagian } \\
\text { yang } \\
\text { kurang } \\
\text { baik }\end{array}$ \\
\hline 3 & $\begin{array}{l}60 \&- \\
75 \%\end{array}$ & $\begin{array}{l}\text { Cukup } \\
\text { Layak }\end{array}$ & $\begin{array}{l}\text { Produk } \\
\text { dapat } \\
\text { diakai } \\
\text { dengan } \\
\text { merevis } \\
\text { i bagian } \\
\text { yang } \\
\text { merupa } \\
\text { kan } \\
\text { kelemah } \\
\text { an } \\
\end{array}$ \\
\hline 4 & $\begin{array}{l}76 \%- \\
85 \%\end{array}$ & Layak & $\begin{array}{l}\text { Produk } \\
\text { dapat } \\
\text { dilanjut } \\
\text { kan dan } \\
\text { menam } \\
\text { bahkan } \\
\text { hal-hal } \\
\text { yang } \\
\text { diangga } \\
\text { p } \\
\text { kurang }\end{array}$ \\
\hline 5 & $\begin{array}{l}86 \%- \\
100 \%\end{array}$ & $\begin{array}{l}\text { Sangat } \\
\text { Layak }\end{array}$ & $\begin{array}{l}\text { Produk } \\
\text { siap } \\
\text { dipakai } \\
\text { dilapan } \\
\text { gan } \\
\text { tanpa } \\
\text { revisi }\end{array}$ \\
\hline
\end{tabular}

Sumber : Purwanto ( 2013:105)

Rentang Nilai Berdasarkan Katagori

\begin{tabular}{|l|c|}
\hline Kategori & Rentang Nilai \\
\hline Sangat Tinggi & $80-100$ \\
\hline Tinggi & $66-79$ \\
\hline Sedang & $55-65$ \\
\hline Kurang & $42-55$ \\
\hline Rendah & $<40$ \\
\hline
\end{tabular}

Sumber: Arikunto dan Cepi (2014:145)

c. Tes dalam penelitian ini digunakan untuk mengukur tingkat efektifitas penggunaan produk yang dikembangkan. Tes diberikan sebanyak 2 kali berupa pretes dan postes.

\section{HASIL DAN PEMBAHASAN}

Uji coba pemakaian media dilakukan oleh siswa kelas I SDN No.024 yang dibagi menjadi 2 kelompok yaitu uji coba kelompok kecil dan uji coba lapangan. Uji coba kelompok kecil dilakukan oleh 28 siswa kelas ID dan uji coba lapangan dilakukan oleh 84 siswa kelas ID, IC dan IE. Dari uji coba pemakaian media ini diketahui respon serta diperoleh komentar dan saran untuk penyempurnaan produk kartu huruf sukukata. Langkah terakhir adalah melakukan analisis data dari data yang diperoleh selama penelitian dan pengembangan.

Dalam analisis kebutuhan ini, telah diujicobakan pada kelompok kecil berjumlah 28 orang siswa dan 84 orang siswa dalam uji lapangan. Berdasarkan hasil observasi oleh kepala sekolah, dapat dideskripsikan bahwa media kartu sukukata cenderung belum pernah melakukan pembinaan secara khusus dalam pengembangan media pembelajaran yang berpusat pada siswa. minimnya pembinaan yang dilakukan oleh kepala sekolah tersebut disebabkan karena pemahaman kepala sekolah tentang media pembelajaran yang kurang memadai.

Oleh karena itu, kepala sekolah menyatakan sangat mengharapkan adanya upaya penelitian pengembangan media pembelajaran berpusat pada siswa. Kepala sekolah menyatakan akan memberikan kesempatan dan dukungan bagi para guru untuk mengikuti program pelatihan pengembangan media pembelajaran berpusat pada siswa.

Alasan guru menggunakan media dalam pembelajaran, hingga dapat meningkatkan proses pembelajaran. Guru yang menyatakan bahwa mereka sangat perlu dan mengharapkan adanya upaya pengembangan media pembelajaran, mereka memandang sangat perlu upaya itu dilakukan, mereka mendukung upaya pengembangan dan mereka akan menyiapkan diri untuk terlibat dalam proses pengembangan dan implementasi produk media pembelajaran.

Uji coba pemakaian media dilakukan oleh siswa kelas I SDN No.024 yang dibagi menjadi 2 kelompok yaitu uji coba kelompok kecil dan uji coba lapangan. Uji coba kelompok kecil dilakukan oleh 28 siswa kelas ID dan uji coba lapangan dilakukan oleh 84 siswa kelas ID, IC dan IE. Dari uji coba pemakaian media ini diketahui respon serta diperoleh komentar dan saran untuk penyempurnaan produk kartu huruf sukukata. Langkah terakhir 
adalah melakukan analisis data dari data yang diperoleh selama penelitian dan pengembangan.

Dalam analisis kebutuhan ini, telah diujicobakan pada kelompok kecil berjumlah 28 orang siswa dan 84 orang siswa dalam uji lapangan. Berdasarkan hasil observasi oleh kepala sekolah, dapat dideskripsikan bahwa media kartu sukukata cenderung belum pernah melakukan pembinaan secara khusus dalam pengembangan media pembelajaran yang berpusat pada siswa. minimnya pembinaan yang dilakukan oleh kepala sekolah tersebut disebabkan karena pemahaman kepala sekolah tentang media pembelajaran yang kurang memadai.

Oleh karena itu, kepala sekolah menyatakan sangat mengharapkan adanya upaya penelitian pengembangan media pembelajaran berpusat pada siswa. Kepala sekolah menyatakan akan memberikan kesempatan dan dukungan bagi para guru untuk mengikuti program pelatihan pengembangan media pembelajaran berpusat pada siswa.

Alasan guru menggunakan media dalam pembelajaran, hingga dapat meningkatkan proses pembelajaran. Guru yang menyatakan bahwa mereka sangat perlu dan mengharapkan adanya upaya pengembangan media pembelajaran, mereka memandang sangat perlu upaya itu dilakukan, mereka mendukung upaya pengembangan dan mereka akan menyiapkan diri untuk terlibat dalam proses pengembangan dan implementasi produk media pembelajaran.

Setelah pengujian terhadap kartu suku kata berhasil, maka selanjutnya media tersebut diterapkan dalam kondisi nyata untuk lingkup yang lebih luas, Dalam tahap ini, digunakan metode eksperimen. Setelah pengujian model, masih dimungkinkan ada revisi produk, kemudian barulah menjadi model final, yang siap untuk diseminasi.

Untuk mengetahui efektifitas pembelajaran maka peneiti membutuhkan data dengan mengacu pada kreteria keefektifan sebagai berikut:

a. Mengolah data tercapaian hasil belajar siswa. Dapat dikatakan tuntas apabila sekurangkurangnya $76 \%$ dari jumlah siswa telah mencapai Kreteria Ketuntasan Minimal (KKM) yang ditetapkan yaitu 76 .

b. Membandingkan nilai tes awal dan tes akhir pada uji coba kelompok kecil dan kelompok besar/uji lapangan.

Hasil Keefektifan Media Pembelajaran

\begin{tabular}{|c|l|c|l|}
\hline $\begin{array}{l}\mathrm{N} \\
\mathrm{o}\end{array}$ & Kreteria & $\begin{array}{c}\text { Rata-Rata } \\
\text { Penilaian }\end{array}$ & Keterangan \\
\hline 1 & Observasi & $81,14 \%$ & Efektif \\
. & Siswa & & \\
\hline
\end{tabular}

\begin{tabular}{|c|c|c|c|}
\hline 2 & $\begin{array}{l}\text { Prestasi } \\
\text { Belajar } \\
\text { Anak }\end{array}$ & $78 \%$ & Efektif \\
\hline 3 & $\begin{array}{l}\text { Observasi } \\
\text { Kepala } \\
\text { Sekolah } \\
\end{array}$ & $96,42 \%$ & Efektif \\
\hline 4 & $\begin{array}{l}\text { Ketuntasan } \\
\text { Belajar } \\
\text { Siswa }\end{array}$ & $88 \%$ & Efektif \\
\hline
\end{tabular}

Berdasarkan hasil analisa diatas empat kriteria yang digunakan seluruhnya termasuk efektif. Hal ini berarti media pembelajaran kartu suku kata dapat digunakan pada pembelajaran menbaca awal siswa dikelas I.

Hasil analisis penelitian ini diatas dapat dibuktikan bahwa penggunaan media kartu huruf lebih baik dari siswa yang menggunakan model pembelajaran kontekstual dengan media kartu kata terhadap keterampilan membaca permulaan.

\section{KESIMPULAN}

Berdasarkan hasil penelitian ini dapat disimpulkan sebagai berikut.

1. Pengembangan media pembelajaran kartu suku kata dikembangkan melalui 3 tahap yaitu tahap I Penelitian pendahuluan, tahap II Pengembangan Model, tahap III Implementasi model dan pengujian model (desain produk, validasi desain, revisi desain, ujicoba produk, revisi produk, evaluasi dan penyempurnaan, model akhir hasil revisi). Adapun media yang dihasilkan sebagai media guru dalam pembelajaran membaca awal pada pelajaran 1 terdiri dari, menggabungkan huruf menjadi suku kata, mengeja suku kata menjadi kata, menggabungkan kata menjadi kalimat, membaca suku kata pada kartu suku kata, memasang kata dengan gambar, melengkapi kata dalam kalimat sederhana.

2. Dari hasil pengembangan media pembelajaran kartu suku kata dengan kategori sangat layak dengan skor rata rata yang diberikan oleh ahli materi yaitu 91\% kategori sangat layak, ahli media \& desain yaitu 76,11 kategori layak. Sehingga media pembelajaan kartu suku kata layak sebagai media dalam pelaksanaan pembelajaran membaca awal di kelas I Sekolah Dasar.

3. Efektivitas pengembangan media pembelajaran ditandai oleh hasil belajar ketika belajar uji coba media terhadap siswa dan keberhasilan pelaksanaan pembelajaran berdasarkan perencanaan pembelajaran yang telah dilakukan berdasarkan data yg diperoleh dari uji coba awal kelompok kecil dengan nilai rata rata 
$73,37 \%$ dan nilai akhir uji kelompok kecil meningkat menjadi $87,14 \%$, sedangkan hasil yg dicapai pada uji awal kelompok besar atau uji lapangan nilai rata rata $88,54 \%$ sedangkan uji akhir kelompok besar atau uji lapangan terdapat peningkatan dengan nilai rata rata 89,69\%. Secara umum dapat disimpulkan bahwa pengembangan media pembelajaran kartu suku kata mampu membawa siswa dalam mencapai kriteia ketuntasan minimal $[\mathrm{KKM}]$ yang berlaku yakni 76. Sedangkan respon siswa terhadap pengembangan media pembelajaran pada kompetensi membaca awal sangat positif. Hal ini terungkap dari hasil observasi serta komentar yang disampaikan siswa uji coba kelompok kecil dan uji coba kelompok besar dengan nilai yang sama rata rata 4,5 atau 89,69\% dengan kategori sangat layak. Hasil belajar ini juga telah menunjukan bahwa pengembangan media pembelajaran kartu mampu meningkatkan hasil belajar siswa yang dapat dilihat dari nilai capaian sebelum menggunakan pengembangan dan sesudah menggunakan pengembangan efektivitas juga ditandai oleh keberhasilan dalam pelaksanaan pengembangan media pembelajaran kartu suku kata dengan menggunakan pengembangan media pembelajaran sesuai dengan perencanaan sebelumnya.

\section{DAFTAR PUSTAKA}

Branch, R. M. (2009). International Design: The ADDIE Approach. Springer.

Peraturan Menteri Pendidikan Nasional Republik Indonesia Nomor 20 Tahun 2016. (2016).

Standar Kompetesi Kelulusan (SKL).

Depdiknas.

Peraturan Menteri Pendidikan Nasional Republik Indonesia Nomor 22. (2016). Standar Proses

Pendidikan Dasar dan Menengah. Depdiknas.

Samatowa. (2011). Pembelajaran IPA SD. Indeks.

Sugiyono. (2015). Metode Penelitian \& Pengembangan Research and Development. ALFABETA.

Undang-Undang Republik Indonesia No.20. (2003). Sistem Pendidikan Nasional. Depdiknas.

Wiratmojo, P. dan S. (2002). Media Pembelajaran Bahan Ajar Diktat Kewidyaiswaraan Berjenjang Tingkat. Lembaga Administrasi Negara. 